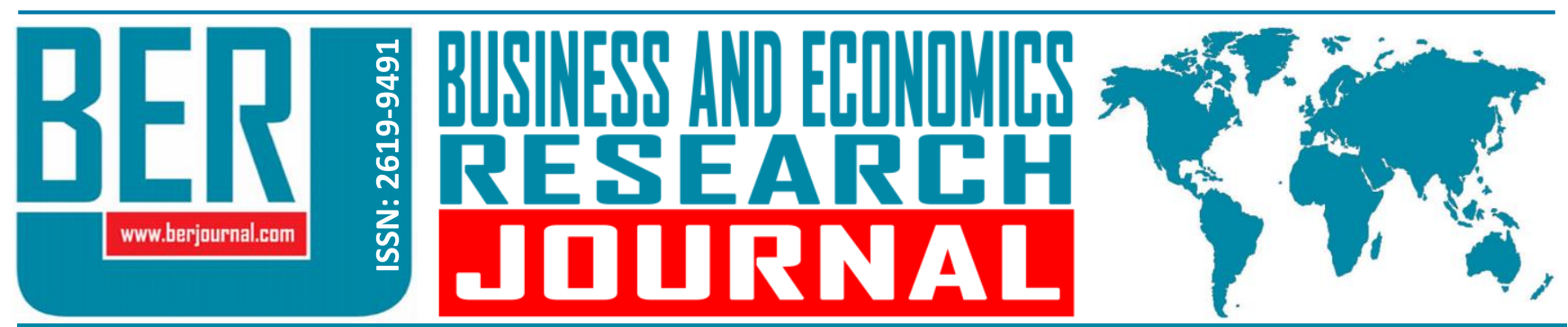

Business and Economics Research Journal Vol. 11, No. 3, 2020, pp. 891-905 doi: 10.20409/berj.2020.288

\section{İş Güvencesizliği, Çalışma Koşulları ve Mesleki Sosyal Statünün Mesleği Bırakma Niyeti Üzerine Etkisi}

\author{
Handan Ozcelik Bozkurt ${ }^{\mathrm{a}}$, Ali Turan Bayram ${ }^{\mathrm{b}}$
}

Öz: Bu çalışmada; turizm eğitimli otel çalışanlarının iş güvencesizliği, çalışma koşulları ve mesleki sosyal statü algılarının mesleği bırakma niyetleri üzerindeki etkisi incelenmiştir. Bu amaçla, ilgili yazın taranarak değişkenlere ilişkin bilgilere yer verilmiş, değişkenler arasındaki ilişkiye yönelik saptamalar yapılmış ve araştırma modeli meydana getirilmiştir. Modeli test etmek amacıyla Antalya'daki dört ve beş yıldızlı 18 farklı otel işletmesinde 392 turizm eğitimi almış çalışanın katılım gösterdiği bir anket uygulaması yapılmıştır. Yapısal eşitlik modellemesi yoluyla değişkenlere doğrulayıcı faktör analizi ve yol analizi uygulanmıştır. Hipotezlerin test edildiği araştırma sonucunda, iş güvencesizliği ile olumsuz çalışma koşullarının mesleği bırakma niyeti üzerinde pozitif, yüksek düzeyde mesleki sosyal statü algısının ise mesleği bırakma niyeti üzerinde negatif etkiye sahip olduğu sonucuna ulaşılmıştır. Elde edilen bulgular doğrultusunda işverenlere, sektör temsilcilerine ve ülkenin ilgili yönetim birimlerine çeşitli önerilerde bulunulmuştur.

\section{The Effect of Job Insecurity, Working Conditions and Occupational Social Status on The Intention to Quit Occupation}

Abstract: In this research; the effects of job insecurity, working conditions and occupational social status perceptions of tourism educated accommodation establishment employees on their intention to quit the profession were investigated. For this purpose, the relevant literature was examined, information about the variables was presented, determinations were made for the relationship between variables, and a research model was created. Confirmatory factor analysis and path analysis were applied to variables through structural equation modeling. In order to test the model, a survey was conducted with 392 employees in 18 different four and five star accommodation establishments in Antalya. As a result of the research in which hypotheses are tested using structural equation modeling, it was concluded that job insecurity and bad working conditions had a positive effect on the intention to quit the occupation and the high level of professional social status perception had a negative effect on intention to quit the occupation. In this direction various suggestions were made to employers, sector representatives and relevant management units of the country.
Anahtar Sözcükler: İ̧̧ Güvencesizliği, Çalışma Koşulları, Mesleki Sosyal Statü, Mesleği Bırakma Niyeti, Turizm

JEL: J24, J81, Z13, J63, 184

$\begin{array}{ll}\text { Geliş } & : 07 \text { Nisan } 2020 \\ \text { Düzeltme } & : 03 \text { Haziran } 2020 \\ \text { Kabul } & : 29 \text { Haziran } 2020 \\ \text { Tür } & : \text { Araştırma }\end{array}$

Keywords: Job Insecurity, Working Conditions, Occupational Social Status, Intention to Quit Occupation, Tourism

JEL: J24, J81, Z13, J63, I84

$\begin{array}{ll}\text { Received } & \text { : } 07 \text { April } 2020 \\ \text { Revised } & \text { : 03 June } 2020 \\ \text { Accepted } & \text { : 29 June } 2020 \\ & \\ \text { Type } & \text { : Research }\end{array}$

Type : Research

a Asst. Prof., PhD., Sinop University, School Of Tourism and Hotel Management, Gastronomy and Culinary Arts Department, Sinop, Turkiye, handanozcelikbozkurt@gmail.com (ORCID ID: 0000-0002-0035-3362)

b Asst. Prof., PhD., Sinop University, School Of Tourism and Hotel Management, Department Of Tourism Guiding, Sinop, Turkiye, alibayram@sinop.edu.tr (ORCID ID: 0000-0003-1655-4043) 


\section{Giriş}

İşletmeler küresel pazarda rekabetin artmasıyla birlikte verimliliklerini, temel yetkinliklerini ve şirketlerinin krizlere karşı elastikiyetini artırmak adına yoğun çaba sarf etmektedirler. Bu doğrultuda stratejik ittifaklar, örgütsel küçülme, müşterilerin ihtiyaçlarını karşılamak adına yönetim stratejileri geliştirme, işletmenin yeniden yapılandırılması, dış kaynak kullanımı, gibi pek çok yola başvurulmaktadır. Ayrıca teknolojinin ilerlemesi ve iş piyasasına otomasyonun her geçen gün daha fazla dahil olması çalışanlarda iş güvencesizliği algısının yaygınlaşması ihtimalini ortaya çıkarmaktadır.

Mevsimsellik, siyasi ilişkiler, doğal afetler, ekonomik kriz vb., pek çok etken turizm sektörü için kaygan bir zemin hazırlamaktadır. Bu durumun sektör çalışanlarının kariyer bağlııklarını etkileyerek mesleği bırakmalarına neden olması da muhtemeldir. Bu bağlamda turist talep elastikiyetinin son derece yüksek olduğu turizm sektöründe, çalışanların iş güvencesizliği algılarının ölçülmesi ve söz konusu algının mesleği bırakma eğilimine olan etkilerini belirlemek son derece önemlidir.

Turizm, emek-yoğun bir hizmet sektörüdür. Dolayısıyla bu durumun çalışanların fiziksel çalışma koşullarını etkilemesi de muhtemeldir. Turizm eğitimi alan ve staj yapan öğrenciler, staj yapmayan öğrencilere kıyasla sektöre daha olumsuz bakmaktadırlar (Kozak ve Kızılırmak, 2001; Kuşluvan, Kuşluvan ve Eren, 2003; Emir, Pelit ve Arslan, 2010). Kaynağın anlaşıması bakımından turizmde çalışma koşullarının incelenmesi sektör ve çalışanlar için faydalı olacaktır.

Modern hizmet ve sanayi ekonomileri, çok sayıda ve farklı işler içeren mesleklerle karakterizedir. Bir mesleğe ait çeşitli özellikler (ücret, fiziksel çalışma koşulları, iş güvenliği, iş güvencesi vb.,) toplum nezdinde o mesleğe dair genel bir imaj çizebilmektedir. Bu bakımdan çalışanlar için mevcut işin mesleki sosyal statü algı düzeyinin mesleği bırakma veya mesleğe devam etme kararı üzerindeki etkisini belirlemek önemlidir. Aynı zamanda turizm işletmesi çalışanlarının mesleki sosyal statü algı düzeylerinin belirlenmesi için de fayda sağlayacaktır.

Turizm eğitimi alan bireylerin sektörde çalışma konusunda isteksiz olmaları birçok ülkede var olan bir sorundur (Kuşluvan ve Kuşluvan, 2000; King, McKercher ve Wayszak, 2003; Blomme, Tromp ve Rheede, 2008). Hollanda'da turizm okulu mezunlarından $\% 70$ 'inin ortalama 6 yıl sonra turizm sektörünü terk ettiği tespit edilmiştir (Blomme, 2006).

Konunun öneminden hareketle bu çalışmanın amacı; turizm eğitimi almış otel çalışanlarının iş güvencesizliği algılarının, çalışma koşullarının ve mesleki sosyal statü algılarının mesleği bırakma niyetleri üzerindeki etkisini ortaya koymaktır.

\section{Teorik Çerçeve}

\section{1. İ̧̧ Güvencesizliği}

İlgili yazında iş güvencesizliği kavramını farklı şekilde tanımlayan çalışmalara rastlamak mümkündür. Greenhalg ve Rosenblatt (1984)' a göre iş güvencesizliği; bireyin mevcut işindeki sürekliliği konusunda kontrolünün olmaması durumudur. Joelson ve Wahlouist (1987)'e göre çalışanın mevcut işinde devamlılığı konusundaki potansiyel bir tehdittir. Hartley, Jacobsson, Klandermans ve Van Vuuren (1991) ve De Witte (1999)'ye göre ise bireyin kontrolü dışında gelişen faktörlere bağlı olarak meydana gelen iş kaybı tehdididir. Hellgren, Sverke ve Isaksson (1999) iş güvencesizliğini iki farklı şekilde sınıflandırmışlardır. Buna göre nicel iş güvencesizliği; bireyde var olan işin kendisini kaybetme endişesidir. Nitel iş güvencesizliği; bireyin çalışma koşullarının kötüleşmesi, kariyer fırsatlarının ve maaşının azalmasına yönelik korkularını ifade etmektedir. Mevcut bir istihdam durumunun geleceğine ilişkin belirsizlik olarak tanımlanan iş güvencesizliği "nesnel" veya "öznel/algılanan" iş güvensizliği olarak ayırt edilebilir. Nesnel iş güvencesizliği, bir şirkette toplu işten çıkarmaların duyulması gibi çalışanın işini nesnel olarak tehlikeye sokan durumlarda meydana gelmektedir. Öte yandan algılanan iş güvencesizliği, bir bireyin belirli bir durumun öznel değerlendirilmesinden kaynaklanmaktadır ve nesnel bir tetikleyici olmadan ortaya çıkabilmektedir (Sverke, Hellgren ve Naswall, 2002). Yükümlülükler, finansal kaygılar ve sosyo-ekonomik belirsizlikler iş güvencesizliğinin kişide yarattığı stres kaynaklarındandır (Joelson ve Wahlouist, 1987). İş güvencesizliği, özellikle işletmelerin küçülmesi veya 
kapanması durumunda artmaktadır. Aynı zamanda benzer nitelikte yeni bir iş bulma konusunda belirsizlikler taşıyan bireylerde daha fazla görülmektedir (Vance ve Kuhnert, 1989). Bu nedenle iş güvencesizliği özellikle ekonomik kriz yaşanan dönemlerde önemli bir stres kaynă̆ı haline gelmektedir.

\section{2. Çalışma Koşulları}

Çalışma koşulları işgöreni yakından etkileyen fiziksel, sosyal, maddi ve manevi pek çok faktörle ilişkilidir (Şahin ve Karataş, 2015). İşgören tarafından algılanan çalışma koşulları; iş tatmini (Akkaşoğlu ve Ulama, 2016), mesleki yabancılaşma (Seymen, Bolat, Bolat ve Kinter, 2017) ve farklı mesleklere yönelme (Kuşluvan ve Kuşluvan, 2000; Roney ve Öztin, 2007) üzerinde belirleyici bir role sahiptir. Çalışma koşulları çalışanın iş yaşamının yanında iş dışındaki hayatını da (aile ve arkadaş ilişkileri vb.) etkilemektedir (Erdil, Keskin, İmamoğlu ve Erat, 2004). Çalışan yaşamının büyük bir kısmını iş yerinde geçirmektedir. İş stresi gündelik hayatın olumsuz etkileriyle bir araya geldiğinde fiziksel ve ruhsal problemlere yol açmaktadır (Cooper ve Cartwright, 1994). Söz konusu problemler elverişsiz çalışma koşullarıyla bir araya geldiğinde ise çalışanın psikolojik iyi olma halinde pek çok olumsuzluğun meydana gelmesi muhtemeldir.

Turizm, emek-yoğun bir sektör olmakla birlikte dünyada en fazla istihdam sağlayan sektörlerin başında gelmektedir (Bamford, 2012). Konaklama işletmesi çalışanlarının performans düzeylerinde çalışma koşullarının önemi büyüktür (İzgi ve Olcay, 2008). İş piyasasında çoğunlukla üreticiden-tüketiciye yönelik olan dağıtım kanalı, turizm sektöründe ters yönlü işlemektedir. Dolayısıyla hizmet almak isteyen turist arz edilen ürünün olduğu yere gitmek zorundadır. Otel işletmelerinde ise arz edilen hizmettir ve hizmetin en önemli temsilcileri iş görenlerdir. Çalışanların ağırlıklı olarak bedenen hizmet sunduğu turizm sektöründe çalışma koşullarının ilgili yazında ele alınması ve mevcut sorunların belirlenmesi bu bakımdan oldukça önemlidir

\subsection{Mesleki Sosyal Statü}

Meslek, bireyin fiziksel intiyaçlarını yerine getirmesi için gerekli olmakla birlikte; sosyal statü belirleyici bir güce sahiptir. Nesnel sosyal statü; belirli hizmetlere, kaynaklara ve bilgiye erişim sağlayan bir sosyo-ekonomik konuma atfedilen prestij anlamına gelmektedir (Krieger, Williams ve Moss, 1997). Öznel sosyal statü ise bireyin sosyo-ekonomik pozisyonunun başkalarılla ilişkili olarak (toplumunda / topluluğunda) algısına dair bir ölçüttür ve genellikle gelir, eğitim ve benzeri objektif göstergelere dayanmaktadır (Adler ve Stewart, 2014). Toplumun algısına dair mesleki sosyal statü ise öznel sosyal statü içerisinde yer almaktadır (Ferreira, Camelo, Viana, Giatti ve Barreto, 2018). Konuyla ilgili Avrupa'da yapılan çalışmalara bakıldığında kalifiye işçi statüsünün üst sıralarında "beyin işçileri" yer almaktayken kalifiye olmayan iş̧̧i sınıfında ise "el işçileri" vardır. Yine batı toplumlarında yapılan çalışmalarda mesleğin sosyal statü belirlemede önemli güce sahip olduğu görüşü ağır basmaktadır (Mitchell ve Epstein, 1959).

Meslek, sosyal tabakalaşma sistemi içerisinde bireyin sosyal statüsünü başka bir deyişle toplumda işgal ettiği konumunun önemini belirleyen bir faktördür. Meslek faktörü; gelir düzeyi ve hayat tarzı gibi bireyin sosyal statüsünü belirlemede önemli rol oynamakla birlikte ferdin söz konusu sosyal tabakalaşma sistemi içerisinde yatay veya dikey hareketliliğini büyük ölçüde koşullandırmaktadır (Eke, 1987). Bu bakımdan meslek, ferdin toplum içerisinde belirli bir unvan edinmesine olanak sağlayan bir olgudur (Tutkun ve Koç, 2008).

\subsection{Mesleği Bırakma Niyeti}

Mesleği bırakma niyeti, fiilen mesleği bırakmanın en iyi göstergelerindendir (Lee ve Bruvold, 2003). Bununla birlikte mesleği bırakma niyeti gerçek bir eylem değildir (Van Dick vd., 2004). İşten veya meslekten ayrılma; fikrin oluşması ve yeni iş alternatiflerini gözden geçirme gibi eylemler gerektiren zaman alıcı bir süreçtir (Jacqueline ve Milton, 2007). Mesleği bırakma niyetini meydana getiren pek çok örgütsel davranış değişkeni vardır. Söz konusu değişkenlerin etkileri kültüre ve hizmet verilen sektörün niteliklerine göre değişiklik göstermektedir (Turunç, 2011). Mesleği bırakma niyeti, çalışanın mesleğine yönelik edindiği olumsuz algı sonucu meydana gelmektedir (Çiftçioğlu, 2011).

Çin'de turizm okulu öğrencilerinden büyük bir çoğunluğun mezun olduktan sonra sektörde çalışma konusunda istekli oldukları gözlenmiştir (Lu ve Adler, 2009). Tayland'da yapılan bir başka araştırmaya göre de 
turizm bölümü öğrencilerinin \%70,1'i sektörde çalışmayı düşünmektedir (Chen, Chu ve $W u, 2000)$. Türkiye'de turizm eğitimi alan öğrencilerin büyük bir kısmı ise sektör ile alakalı olumsuz algı ve tutuma sahiptir (Aksu ve Köksal, 2005; Üzümcü, Alyakut ve Günsel, 2015). Turizm bölümü öğrencilerine yönelik bir araştırmada mesleği bırakma niyetine; düzensiz ve uzun çalışma saatleri, işin stresli, yorucu ve mevsimlik olması, düşük sosyal statü algısı, adaletsiz terfiler, düşük ücret uygulamaları, niteliksiz amir ve yöneticiler, yöneticilerin çalışanlara kötü davranması, kalifiye olmayan iş arkadaşları ve bu çalışanların saygısız tutumları ve çalışma koşullarının fiziksel yönden kötü olmasının neden olduğu sonucuna ulaşıımıştır (Kuşluvan ve Kuşluvan, 2000). Turizm eğitimi alan bireylerin bir süre sonra turizm sektöründen ayrıldıkları çeşitli çalışmalarla da doğrulanmıştır (King vd., 2003; Blomme, 2006; Walsh ve Taylor, 2007; Blomme vd., 2008).

\subsection{Değişkenler Arasındaki İlişkiler}

İş güvencesizliği ile mesleği bırakma niyeti ilişkisi COR teorisine (Hobfoll, 1989) dayanmaktadır. COR teorisine göre, potansiyel ya da mevcut kaynak kayıplarının meydana gelmesi muhtemeldir. Bu durum bir alandaki kaynak kaybının (örn. nesnel iş güvenliği) diğer alanlarda da kolay kaynak kayıplarına (örn. öznel iş güvenliği) yol açtığını göstermektedir. Böyle bir durumda çalışan enerjisini başka iş alternatiflerine yönlendirerek farklı işletme veya sektörlere yönelmektedir. Bu durum aynı zamanda stres yönetimi teorisine de dayandırımaktadır (Baltes ve Baltes, 1990; Heckhausen, 1997; Heckhausen, Wrosch, ve Schulz, 2010). Herzberg'in íki- Faktör Teorisi de iş güvencesinin algısının iş tatminini arttırdığını savunmaktadır (Herzberg, Mausner ve Snyderman, 1959).

İs güvencesizliği algısının işten ayrılma niyetini artırdığı yapılan çeşitli çalışmalarla ortaya konmuştur (Mauno, De Cuyper, Tolvanen, Kinnunen ve Makikangas, 2014; Yıldırım ve Yirik, 2014; Karacaoğlu, 2015; Bozkurt ve Demirel, 2019). Özellikle nitelikli iş gören kaybı, işletme için önemli maliyetler yaratmaktadır (Meier ve Hicklin, 2008). Turizmde özellikle turizm eğitimi alan çalışanların bir süre sonra sektörü terk ettiği çeşitli çalışmalarla tespit edilmiştir (Walsh ve Taylor, 2007; Blomme vd., 2008). Bu durum istihdam algısının azalmasıyla birlikte işten ayrıma niyetinin artmasından dolayı kaynaklanabilmektedir (Bozkurt ve Özkoç, 2018). Akbıyık (2016) sağlık çalışanları üzerine gerçekleştirdiği bir çalışmada iş güvencesizliği algılayan çalışanların kariyer bağlııklarının azaldığını gözlemlemiştir. Benzer şekilde Laine, Heijden, Wickstrom, Hasselhorn ve Tackenberg (2009) hemşirelerin iş güvencesizliği algılarının artmasıyla birlikte mesleklerini bırakma niyetlerinin de arttığı sonucunu ortaya koymuşlardır. ilgili yazında yer alan bilgiler ve yukarıda bahsedilen çalışmalar yola çıkılarak araştırmanın birinci hipotezi geliştirilmiştir:

$\mathbf{H}_{1}$ : İş güvencesizliği algısının mesleği bırakma niyeti üzerinde pozitif yönlü bir etkisi vardır.

Çalışma koşulları ile mesleği bırakma niyeti arasındaki ilişki Herzberg'in îki- Faktör Teorisi'ne dayandırılmaktadır. Bu teori içsel ve dışsal iş tatmini ve bu tatmine dayalı duygusal bağııığa odaklanmaktadır. Denetim, çalışma koşulları, iş arkadaşları, ücret, politikalar ve prosedürler, statü, kişisel yaşam ve iş güvenliği dışsal faktörlerdir. Herzberg'e göre bu faktörlerin yokluğu dolaylı olarak iş tatminsizliğine ve işi veya mesleği bırakma niyetine neden olabilmektedir (Herzberg vd., 1959; Herzberg, 1966).

Flinkman, Isopahkala-Bouret ve Salantera (2013) hemşirelere yönelik gerçekleştirdikleri çalışmalarında, genç hemşirelerin \%26'sının mesleği bırakma eğilimi içerisinde olduğunu ve buna neden olan faktörler arasında olumsuz çalışma koşullarının da yer aldığını gözlemlemişlerdir. Tunç, Gitmez ve Boothby (2014) hemşirelerin memnun bir şekilde mesleklerine başladıklarını fakat olumsuz çalışma koşulları nedeniyle meslekleri hakkında olumsuz duygular beslediklerini tespit etmiştir. Dünyanın çeşitli ülkelerinde ve Türkiye'de yapılan çalışmaların birçoğu özellikle turizm eğitimi alan mezunların bir süre sonra mesleği bıraktıklarını ortaya koymuştur (Duman, Tepeci ve Unur, 2006). Pavesic ve Brymer (1990) turizm eğitimi alan mezunlardan önemli bir kısmının turizm sektörünü terk etmelerinde, kötü çalışma koşullarının belirleyici gücünün olduğunu tespit etmişlerdir. Kuşluvan ve Kuşluvan (2000) turizm bölümü öğrencilerinin sektördeki olumsuz çalışma koşulları nedeniyle hayal kırıklığına uğrayıp sektörden uzaklaştıklarını gözlemlemişlerdir. Duman vd. (2006) ise turizm bölümü öğrencilerinin turizm sektöründe kariyer yapmayı istediklerini ama sektördeki çalışma koşullarını olumsuz buldukları sonucuna ulaşmışlardır. illgili yazında yer alan bilgiler ve yukarıda bahsedilen çalışmalar yola çıkılarak araştırmanın birinci hipotezi geliştirilmiştir: 
$\mathbf{H}_{2}$ : Olumsuz çalışma koşullarının mesleği bırakma niyeti üzerinde pozitif yönlü bir etkisi vardır.

Mesleki sosyal statü algısı ile mesleği bırakma niyeti değişkenleri arasındaki ilişki Sosyal Kimlik Teorisi'ne dayandırılmaktadır. Sosyal Kimlik Teorisi Turner (1975) ve Tajfel (1981) tarafından davranış bilimleri alanına kazandırılmıştır. Bu teoriye göre bireyler hem kendilerine atfedilen (cinsiyet, ırk vb.) hem de elde ettikleri (örgütsel ve profesyonel statüler vb.) bakımından gruplara ayırmaktadırlar (Tajfel ve Turner, 1985; Dutton, Dukerich ve Harquail, 1994). Sosyal Kimlik Teorisi grup davranışını mümkün kılan bilişsel bir mekanizma olmasının yanı sıra; iş motivasyonu, bir örgütte kalma veya örgütten ayrılma gibi birçok örgütsel davranışın temelini açıklamaktadır (Ashforth ve Mael, 1989; Dutton vd., 1994; Riketta, 2005; Liu, Li, Shi ve Fang, 2013).

Derin, İlkim ve Yayan (2017) hemşirelerin mesleki prestij algılarının düşük olması durumunda mesleki bağlııklarının azaldığı, mesleği bırakma eğilimlerinin ise arttığı sonucuna ulaşmışlardır. Karakuş (2011) yine hemşirelerin mesleğin toplumdaki imajının iyi olmaması ve diğer olumsuz faktörlerin etkisiyle mesleği bırakma eğiliminde olduğunu gözlemlemiştir. Benzer şekilde Habip ve Sazkaya (2019) taksi şoförlerine yönelik çalışmalarında, mesleki prestij algısının işten ayrılma niyetini artırdığını tespit etmişlerdir. Kyriacou, Coluthard, Hultgren ve Stephens (2002) öğretmenlik eğitimi alan öğrencilerin kariyer seçimlerinde öğretmenlik mesleğinin sosyal açıdan önemli ve değerli olduğu algısının belirleyici faktörler arasında yer alabileceğine dikkat çekmişlerdir. Yılmaz ve Tanrıverdi (2017) aş̧̧ılara yönelik çalışmalarında mesleki sosyal statü algısının mesleki bağlıık üzerinde etkisi olduğunu ortaya koymuşlardır. Saltık, Avcı ve Kaya (2016) mesleki sosyal statü algısının artmasıyla birlikte mesleki bağlılı̆ın arttığını ve mesleki bağıılığın etkisiyle mesleği bırakma niyetinin azaldığını tespit etmişlerdir. Turizmde iş gören devir hızının yüksek olması ise kimi araştırmacılar tarafından turizm sektörüne karşı mesleki sosyal statü algısının düşük olmasına bağlanmıştır (Erdem ve Kayran, 2013). ilgili yazında yer alan bilgiler ve yukarıda bahsedilen çalışmalar yola çıkılarak araştırmanın birinci hipotezi geliştirilmiştir:

$\mathbf{H}_{3}$ : Mesleki sosyal statünün mesleği bırakma niyeti üzerinde negatif yönlü bir etkisi vardır.

\section{Metodoloji}

\subsection{Araştırma Modeli ve Yöntem}

Illgili yazından yola çıkılarak iş güvencesizliği, çalışma koşulları ve mesleki sosyal statünün mesleği bırakma niyeti ile etkileşimine yönelik bir araştırma modeli oluşturulmuştur. Şekil 1'de oluşturulan yapısal modelden hareketle iş güvencesizliği, çalışma koşulları ve mesleki sosyal statünün mesleği bırakma niyeti değişkenleri arasındaki etkileşim incelenecektir.

Şekil 1. Araştırmanın Yapısal Modeli

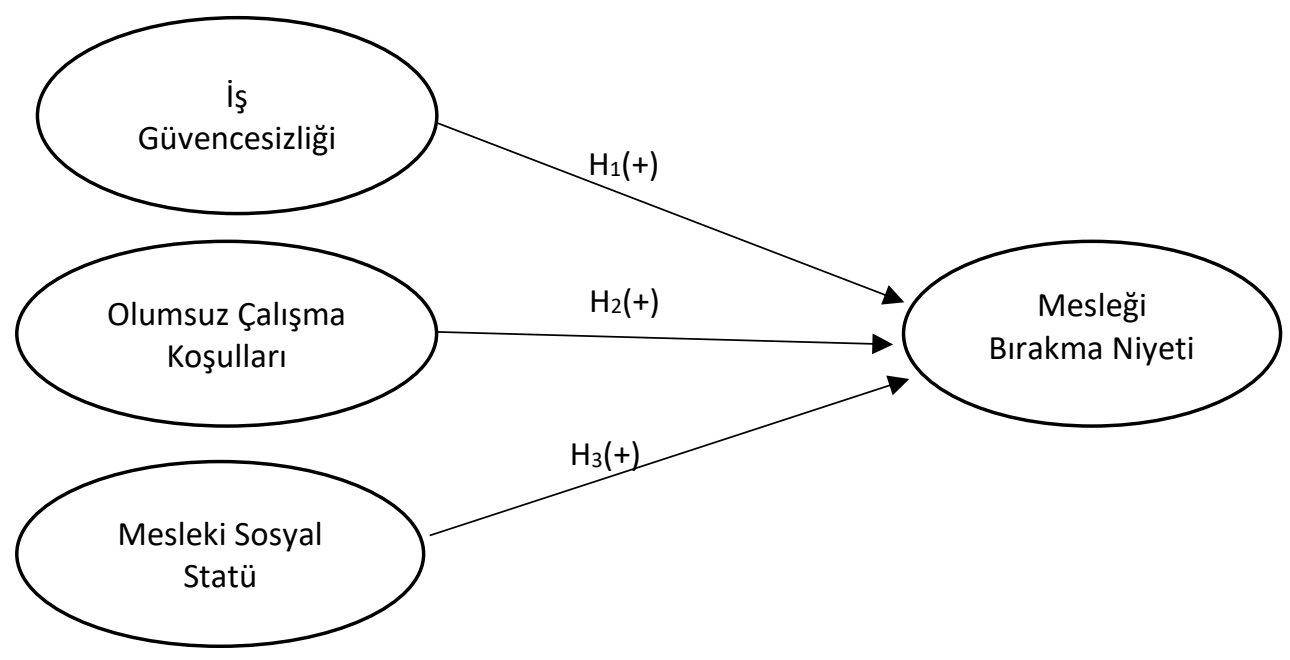


Araştırmanın teorik içeriğinden faydalanılarak oluşturulan modeli test etmek için otel çalışanlarına yönelik bir anket çalışması yapılmış ve geliştirilen üç hipotez AMOS 22 Programı kullanılarak istatistiki yöntemlerle test edilmiştir.

\subsection{Araştırmada Kullanılan Ölçekler}

Araştırmada kullanılan anket formunun ilk bölümünde otel çalışanlarının iş güvencesizliği algılarının ölçülmesi amacıyla Probst (1998) tarafından geliştirilen tek boyutlu ve altı maddeden oluşan "iş güvencesizliği" kullanılmıştır. Ölçek; Önder ve Wasti (2002) tarafından Türkçeye İş Güvencesi Endeksi olarak uyarlanmıştır. Analziler sonucu “iş güvencesizliği” ölçeğinin Cronbach Alpha değeri 0,80 olarak belirlenmiştir.

Anket formunun ikinci bölümünde otel çalışanlarının çalışma koşulu algılarının belirlenmesi amacıyla Kuşluvan ve Kuşluvan (2000)'ın geliştirdiği ve Duman vd. (2006)'nin sadeleştirdiği dokuz maddeden oluşan "işin doğası ve fiziksel çalışma koşulları" ölçeği kullanılmıştır. Pilot çalışma ve ilerleyen veri toplama süreci sonrası ölçeğin iki maddesinin faktör yükünü bozduğu tespit edilmiş ve söz konusu iki madde ankete dahil edilmemiştir. Araştırmada kullanılan ölçeğin Cronbach Alpha değerinin 0,73 olduğu gözlenmiştir.

Anket formunun üçüncü bölümünde otel çalışanlarının mesleki sosyal statü algılarının belirlenmesi amacıyla Kuşluvan ve Kuşluvan (2000) tarafından geliştirilen dört maddeli "mesleki sosyal statü algısı" ölçeği kullanılmıştır. Araştırmada kullanılan ölçeğin Cronbach Alpha değeri 0,71 olarak belirlenmiştir.

Düzenlenen anket formunun dördüncü bölümünde otel çalışanlarının mesleği bırakma niyetlerinin belirlenmesi amacıyla Weng ve McElroy (2012)'un dört maddeli "mesleği sürdürme/bırakma niyeti" ölçeğinden faydalanılmıştır. Araştırmada kullanılan ölçeğin Cronbach Alpha değerinin 0,84 olduğu gözlenmiştir.

Anket formunun son bölümünde ise otel çalışanlarının demografik özelliklerini ve mesleki niteliklerini belirlemeye yönelik sorular yer almaktadır.

\section{3. Örneklem ve Veri Toplama}

Antalya Türkiye'nin turizm başkenti olarak nitelendirilmektedir ve Türkiye'de en çok otel sayısına sahip olan kenttir (Kültür ve Turizm Bakanlığı, 2019). Antalya'da bulunan otellerin 407'si beş yıldızlı otel ve birinci sınıf tatil köyüdür. Bu otellerin 208'i dört yıldızlı, 120'si üç yıldızlı, 37'si iki ve dokuz tanesi bir yıldızlı otel ve ikinci sınıf tatil köyleridir. Araştırma evreninin hesaplanmasında mesafe, zaman ve maliyet gibi faktörler değerlendirilerek örneklem alma yönteminin kullanılması uygun bulunmuş ve olasılığa dayalı olmayan örnekleme tekniklerinden biri olan kolayda örnekleme yöntemi tercih edilmiştir. Kültür ve Turizm Bakanlığı Otelcilik ve Turizm Endüstrisi İ̧̧gücü Araştırması'na (1989) göre beş yıldızlı otellerde yatak başına düşen personel 0,59'dur. Ağaoğlu'nun "işgücünün verimli kullanılması” adlı çalışması da bu hesaplamayı destekler niteliktedir. Antalya'da bulunan beş yıldız otellerin yatak kapasitesi 281.954'tür. Yatak kapasitesinin personel sayısı ile çarpılmasıyla 281.954 x 0,59 = 166.352 sayısına ulaşılmaktadır. Elde edilen bu sonuçla araştırma evreni büyüklüğü tespit edilmiştir. Simple Size Calculator ile de evren örneklemi hesaplanmıştır (http://www.surveysystem.com/sscals.htm). Güven düzeyi \%95 güven aralığı 5'tir. Hesaplama sonucunda örneklem büyüklüğünün 383 olduğu gözlenmiştir. Araştırmaya katılması planlanan örneklemin turizm eğitimli çalışanlar olması ve Antalya'daki turizm eğitimli personel sayısına ulaşılamaması nedeniyle 383 örneklem sayısı üzerinden hareket edilmiştir.

Araştırma anketleri Antalya'da bulunan ve otellerinde anket uygulamasına izin veren 18 farklı dört ve beş yıldızlı otelde sahaya sunulmuştur. Anketlerin uygulandığı oteller Beldibi, Kemer, Göynük, Tekirova, Belek ve Kundu bölgelerinde yer almaktadır. 2019 yılı Temmuz- Eylül ayları arasında uygulanan anketlerin 500 tanesi bırak topla yöntemiyle elde edilmiştir. Anketlere yalnızca turizm eğitimi alan ve stajyer olmayan çalışanların katılması sağlanmıştır. Bırakılan anket formlarının 434 tanesi geri dönmüş bunlardan 392 tanesi değerlendirilmiştir. Değerlendirmeye alınmayan 42 anket eksik ve hatalı doldurulmuştur.

Ankete katılan otel çalışanlarının 181'i $(\% 46,1)$ kadın, 211'i $(\% 53,8)$ erkek katılımcılardan oluşmaktadır. Çalışanların 232'si (\%59,1) evli, 160' ı (\%40,8) bekardır. Katılımcılar ağırlıklı olarak 25-44 (n=366, 
\%93,3) yaş aralığında oldukları tespit edilmiştir. Ankete katılanların 54'ü $(\% 13,7)$ turizm lisesi, 205'i $(\% 52,2)$ turizm ön lisans programı, 131'i $(\% 33,4)$ turizm lisans veya lisans üstü programı mezunudur. Katılımcıların $209^{\prime}$ u (\%53,3) ön büro, 150'si $(\% 38,2)$ yiyecek-içecek departmanı, 17'si $(\% 4,3)$ kat hizmetleri, 16'sı $(\% 4,0)$ muhasebe, insan kaynakları ve satış pazarlama departmanlarında görev yapmaktadır.

\section{Bulgular}

\subsection{Tanımlayıcı İstatistikler ve Korelasyon Analizi}

Değişkenlere ilişkin çarpıklık ve basıklık değerlerinin yer aldığı Tablo 1'de verilen normal dağılım gösterip göstermediğini test etmek amaçlanmıştır. Değişkenlere ilişkin çarpıklık ve basıklık katsayılarının \pm 2 arasında olması verilerin normal dağılım gösterdiğine işaret etmektedir (Tabachnick ve Fidell 2013). Analiz sonucunda ortaya çıkan katsayıların \pm 2 arasında olduğu görülmektedir. Buna göre araştırmada yer alan tüm değişkenlerin normal dağılım gösterdiği söylenilebilir.

Tablo 1. Değişkenlere iliş̧in Çarpıklık ve Basıklık Katsayıları

\begin{tabular}{|l|c|c|c|c|}
\hline & IG & OÇK & MSS & MBN \\
\hline N & 392 & 392 & 392 & 392 \\
\hline Çarpıklık (Skewness) & $-0,347$ & $-0,261$ & 0,234 & 0,142 \\
\hline Std. Hata (Çarpıklık) & 0,123 & 0,123 & 0,123 & 0,123 \\
\hline Basıklık (Kurtosis) & $-0,108$ & 0,273 & 0,233 & 0,534 \\
\hline Std. Hata (Basıklık) & 0,240 & 0,240 & 0,240 & 0,240 \\
\hline $\begin{array}{l}\text { IG: İş Güvencesizliği; OÇK: Olumsuz Çalışma Koşulları; MSS: Mesleki Sosyal Statü; } \\
\text { MBN: Mesleği Bırakma Niyeti }\end{array}$
\end{tabular}

Araştırmada yer alan dört değişkene ilişkin aritmetik ortalamalar incelendiğinde, iş güvencesizliği $(x=2,6)$, olumsuz çalışma koşulları $(x=4,0)$, mesleki sosyal statü $(x=3,1)$, mesleği bırakma niyeti değişkeninin ise $(x=3,2)$ düzeyinde bir ortalamaya sahip olduğu görülmektedir.

Tablo 2. Aritmetik Ortalamalar, Standart Sapmalar ve Korelasyon Katsayıları

\begin{tabular}{|l|c|c|c|c|c|c|}
\hline Değişkenler & $\begin{array}{c}\text { Aritmetik } \\
\text { Ortalama }\end{array}$ & $\begin{array}{c}\text { Standart } \\
\text { Sapma }\end{array}$ & $\mathbf{1}$ & $\mathbf{2}$ & $\mathbf{3}$ & $\mathbf{4}$ \\
\hline İş Güvencesizliği (1) & 2,6 & 1,13 & 1 & & & \\
\hline Olumsuz Çalışma Koşulları (2) & 4,0 & 0,78 & 0,21 & 1 & & \\
\hline Mesleki Sosyal Statü (3) & 3,1 & 1,09 & $-0,46$ & $-0,20$ & 1 & \\
\hline Mesleği Bırakma Niyeti (4) & 3,2 & 1,06 & 0,53 & 0,29 & 0,64 & 1 \\
\hline
\end{tabular}

Tablo 2' de araştırma modelinde yer alan değişkenler arasındaki korelasyon düzeyleri yer almaktadır. Tüm değişkenler arasında 0,01 düzeyinde anlamlılığın olduğu tespit edilmiştir. Buna göre, iş güvencesizliği değişkeni ile olumsuz çalışma koşulları değişkeni arasında $(0,21)$ pozitif yönlü zayıf düzeyde, iş güvencesizliği değişkeni ile mesleki sosyal statü değişkeni arasında $(-0,46)$ negatif yönlü orta düzeyde, iş güvencesizliği ile mesleği bırakma niyeti değişkeni arasında $(0,53)$ pozitif yönlü orta düzeyde, olumsuz çalışma koşulları değişkeni ile mesleki sosyal statü değişkeni arasında $(-0,20)$ negatif yönlü zayıf düzeyde, olumsuz çalışma koşulları ile mesleği bırakma niyeti arasında $(0,29)$ pozitif yönde zayıf düzeyde, mesleki sosyal statü değişkeni ile mesleği bırakma niyeti değişkenleri arasında ise $(0,64)$ pozitif yönde yüksek düzeyde ilişki tespit edilmiştir.

Çoklu regresyon analizi yapılan çalışmalarda bağımsız değişkenler arasında çoklu bağlantılık (multicollinearity) sorunu ortaya çıkabilmektedir. Bu durum bağımsız değişkenler arasında güçlü etkileşim olması nedeniyle meydana gelmektedir (Hair vd., 1998). Araştırmada yer alan değişkenler arasında çoklu 
bağlantının var olup olmadığını ortaya koymak amacıyla varyans büyüme faktörü (Variance Inflation Factor, VIF) değerinin 10'dan küçük olması gerekmektedir. Aynı zamanda varyans değerinin 0,10'dan küçük olup olmadığına bakılmaktadır (Büyüköztürk, 2010). Analizler sonucunda varyans büyüme faktörü (VIF) değerlerinin $10^{\prime}$ dan küçük $(0,70-1,2)$ olduğu tolerans değerlerinin ise $0,10^{\prime}$ dan büyük olduğu tespit edilmiştir. Dolayısıyla var olan modelin çoklu regresyon analizi için uygun olduğu sonucuna ulaşılmıştır (Hair vd., 1998; Altınışık vd., 2007).

\subsection{Doğrulayıcı Faktör Analizi}

Öncelikle kurulan yapısal modelde gözlenen değişkenlerin, örtük değişkenleri etkileme oranını ve ifadelerin faktör yüklerini ortaya koymak amacıyla doğrulayıcı faktör analizi yapılmıştır. Modelde yer alan her bir değişken için tek faktörlü doğrulayıcı faktör analizi uygulanmıştır. Tablo 3’te doğrulayıcı faktör analizinde saptanan uyum iyiliği değerleri yer almaktadır.

Tablo 3. Doğrulayıcı Faktör Analizi Uyum Ölçüleri

\begin{tabular}{|l|c|c|c|c|c|c|}
\hline Uyum Ölçüleri & X2/df & RMSEA & NFI & CFI & GFI & AGFI \\
\hline iş Güvencesizliği & 1,99 & 0,054 & 0,98 & 0,93 & 0,95 & 0,88 \\
\hline Olumsuz Çalışma Koşulları & 2,43 & 0,060 & 0,90 & 0,92 & 0,95 & 0,89 \\
\hline Mesleki Sosyal Statü & 1,57 & 0,052 & 0,91 & 0,94 & 0,90 & 0,86 \\
\hline Mesleği Bırakma Niyeti & 1,96 & 0,050 & 0,90 & 0,95 & 0,90 & 0,87 \\
\hline
\end{tabular}

İş güvencesizliği ölçeğine yapılan DFA sonucunda elde edilen uyum indekslerinin uyum kriterlerini sağladığı gözlenmiştir ( $\chi 2 / \mathrm{df}=1,99, \mathrm{RMSEA}=0,054, \mathrm{NFI}=0,98, \mathrm{CFI}=0,93, \mathrm{GFI}=0,95, \mathrm{AGFI}=0,88$ ). Buna göre, bu çalışma çerçevesinde iş güvencesizliği ölçeğinin tek faktörlü yapısı da doğrulanmıştır. Olumsuz çalışma koşulları ölçeğine yapılan DFA sonucunda elde edilen uyum indekslerinin uyum kriterlerini sağladığı tespit edilmiştir ( $X 2 / \mathrm{df}=2,43 \mathrm{RMSEA}=0,060, \mathrm{NFI}=0,90, \mathrm{CFI}=0,92, \mathrm{GFI}=0,95, \mathrm{AGFI}=0,89$ ). Mesleki sosyal statü ölçeğine yapılan DFA sonucunda elde edilen uyum indekslerinin uyum kriterlerini sağladığı görülmüştür ( $\chi 2 / d f$ $\mathrm{f}=1,57, \mathrm{RMSEA}=0,052, \mathrm{NFI}=0,91, \mathrm{CFI}=0,94, \mathrm{GFI}=0,90, \mathrm{AGFI}=0,86$ ). Mesleği bırakma niyeti ölçeğine ilişkin DFA sonucunda elde edilen uyum indekslerine bakıldığında, ölçeğin uyum kriterlerini sağladığı gözlenmiştir $(\chi 2 / d f=1,96, R M S E A=0,050, N F I=0,90, C F I=0,95, \mathrm{GFI}=0,90, \mathrm{AGFI}=0,87$ ) (Munro, 2005; Çokluk, Şekercioğlu ve Büyüköztürk 2010; Meydan ve Şeşen, 2011; Karacaoğlu, 2015).

\subsection{Model Uyum Değerleri ve Hipotez Testleri}

Turizm eğitimi alan otel çalışanlarının iş güvencesizliği, olumsuz çalışma koşulları ve mesleki sosyal statü algılarının mesleği bırakma niyetlerine etkisini belirlemek amacıyla değişkenlere ilişkin nedensellik ilişkisi, yapısal eşitlik modellemesi (YEM) yoluyla test edilmiştir.

YEM, değişkenler arasındaki doğrudan ve dolaylı etkileri tek bir model içerisinde test etmek için kullanılmaktadır (Meydan ve Şeşen, 2011). YEM, örtük değişkenler arasında bir nedensellik ilişkisinin mevcut olduğunu ve örtük değişkenlerin gözlenen değişkenler vasıtasıyla ölçülebileceğini ileri sürmektedir (Karacaoğlu, 2015). Bu araştırmada iş güvencesizliği, olumsuz çalışma koşulları, mesleki sosyal statü ve mesleği bırakma niyeti örtük değişken, ölçek ifadeleri ise gözlenen değişkendir.

Şekil 2'de örtük değişkenlerin yön ve kuvvet düzeylerine bakılacak olursa iş güvencesizliğinin mesleği bırakma niyetine $(\beta=0,25 ; p<0,001)$ oranında pozitif yönde ve düşük düzeyde etki ettiği görülmektedir. Mesleği bırakma niyetine ilişkin değişimin yalnızca 0,062'si araştırma modelinde yer alan iş güvencesizliği bağımsız değişkeni tarafından açıklanmaktadır. Bir başka deyişle otel çalışanlarının mesleği bırakma niyetleri düzeyindeki değişimin \%6,2'si iş güvencesizliğinin açıkladığı görülmektedir. 
Şekil 2. Yol Analizi

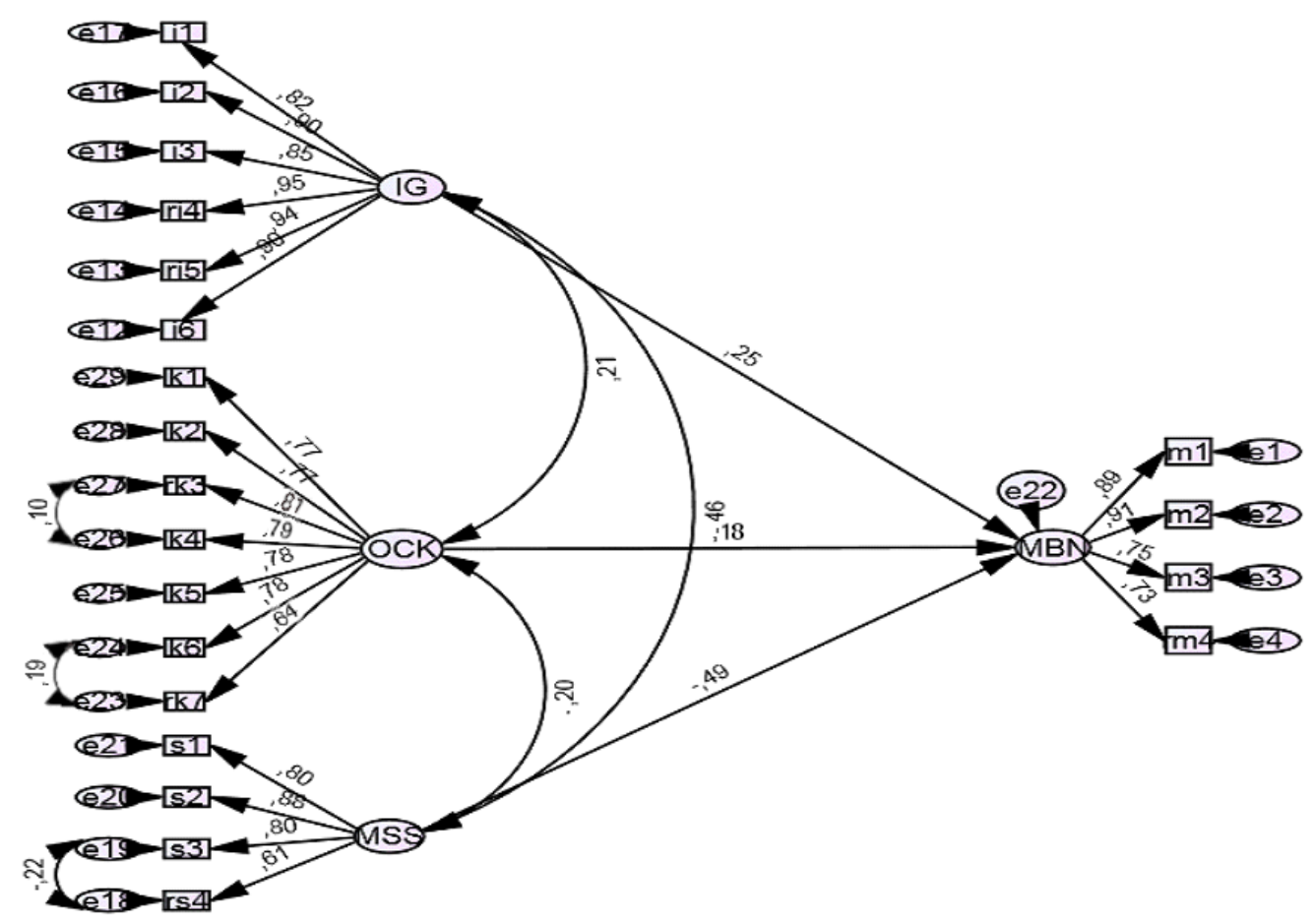

$\chi 2$ dff: 2,68; RMSEA: 0,079; NFI: 0,902; CFI: 0,920; GFI: 0,903; AGFI:0,868

$R^{2}: 0,043$ (IG); $R^{2}: 0,032$ (OCK); $R^{2}: 0,24$ (MSS)

Olumsuz çalışma koşullarının mesleği bırakma niyetini $(\beta=0,18 ; p<0,001)$ oranında pozitif yönde ve düşük düzeyde etkilediği tespit edilmiştir. Mesleği bırakma niyetine ilişkin değişimin 0,032'si araştırma modelinde yer alan olumsuz çalışma koşulları değişkeni tarafından açıklanmaktadır. Dolayısıyla otel çalışanlarının mesleği bırakma niyetlerinin ortaya çıkmasına neden olan faktörlerden biri olan olumsuz çalışma koşullarının \%3,2 gibi düşük düzeyde bir istatiksel değer tarafından açıklandığı görülmektedir.

Mesleki sosyal statü algısının ise mesleği bırakma niyetine $(\beta=-0,49 ; p<0,001)$ oranında ve orta düzeyde negatif yönde etki ettiği sonucuna varılmıştır. Mesleği bırakma niyetine ilişkin değişimin $0,24^{\prime}$ ü mesleki sosyal statü algısı değişkeni tarafından açıklanmaktadır. Bir başka deyişle otel çalışanlarının mesleği bırakma niyetleri düzeyindeki değişimin \%24'ünü mesleki sosyal statünün açıkladığı görülmektedir. Ayrıca olumsuz çalışma koşulları ( 3 ve 4. ifadeler), ( 6 ve 7. ifadeler) ve mesleki sosyal statü algısı (3 ve 4. ifadeler) ölçeklerinde kimi maddeler arasında ortak değişkenliğin olması nedeniyle modifikasyon yapılmış ve bu sayede uyum iyiliği değerlerinde önemli iyileşme sağlanmıştır. Ayrıca bağımsız değişkenler arasında kovaryans çizilmiş ve korelasyon kat sayılarına yer verilmiştir. Elde edilen sonuçlara göre $H_{1}, H_{2}$ ve $H_{3}$ hipotezleri kabul edilmiştir.

\section{Sonuç}

Araştırma sonucunda elde edilen verilere göre; iş güvencesizliği, olumsuz çalışma koşulları ve mesleki sosyal statü algısı mesleği bırakma niyetinin üç farklı yordayıcısıdır. Çalışmanın bulguları, turizm eğitimli otel çalışanlarının iş güvencesizliği algılarının mesleği bırakma niyetlerini pozitif yönde etkilediğini ortaya koymuştur. Bu sonuca göre iş güvencesizliği algısı yüksek olan çalışanların mesleği bırakma niyeti gösterdikleri söylenebilir. İlgili yazında iş güvencesizliği ve mesleği bırakma niyetini inceleyen yalnızca bir çalışmaya rastlanmıştır. Laine vd. (2009)'ne ait olan bu çalışma mevcut araştırmanın sonucunu destekler niteliktedir. 
İşten ayrılma niyeti, mesleği bırakma niyetinin öncülü olan bir değişkendir. İş güvencesizliğinin işten ayrılma niyetini artırdığı da çeşitli çalışmalarla doğrulanmıştır (Mauno vd., 2014; Yıldııım ve Yirik, 2014; Karacaoğlu, 2015; Bozkurt ve Demirel, 2019). Araştırmada elde edilen bulgulara göre, iş güvencesizliği algısı yüksek olan turizm eğitimli otel çalışanlarının mesleki bağlııkları düşüktür. Ayrıca elde edilen bulgular istihdam ve iş güvencesinin çoğu çalışan için önemli olduğunu savunan COR teorisiyle örtüşmektedir (Hobfoll, 1989). Araştırmada elde edilen bulgular bu etkinin düşük düzeyde olduğunu göstermiştir. Bu durum turizm sektöründe mevcut işin alternatiflerinin var olması ya da farklı sektörlerde tatmin edici alternatiflerin olmayışından kaynaklanabilir. İş güvencesizliği turizm eğitimi alanlar, turizm eğitimi almakta olanlar ve potansiyel turizm bölümü öğrencileri için önemli bir tehdittir. Söz konusu bireylerin yaşam kalitesi, psikolojik iyi olma halleri ve beşeri ihtiyaçları gibi pek çok faktör iş güvencesi sağlayan bir mesleğe sahip olmalarından geçmektedir. Öte yandan nitelikli iş gücünün başka iş kollarına yönelmesi işveren ve sektör açısından da kalite sorununu ortaya çıkarmaktadır.

Çalışmada turizm eğitimli otel çalışanlarının olumsuz çalışma koşulları algılarının artmasıyla birlikte mesleği bırakma niyetlerinin arttığı tespit edilmiştir. Dolayısıyla olumsuz çalışma koşulları algısı yüksek olan çalışanların mesleği bırakma niyetleri yüksektir. Bu sonuç ilgili yazında yer alan birçok çalışma ile benzerlik göstermektedir (Pavesic ve Brymer 1990; Kuşluvan ve Kuşluvan 2000; Duman vd., 2006; Flinkman vd., 2013; Tunç vd., 2014). Aynı zamanda elde edilen bulgular Herzberg'in iki-faktör teorisini desteklemektedir (Herzberg vd., 1959; Herzberg, 1966). Ancak araştırmada elde edilen bulgular bu etkinin düşük düzeyde olduğunu göstermiştir. Bu durum turizm sektörünün düzensiz ama eğlenceli bir yapıya sahip olması ile açıklanabilir. Chuang ve Jenkins (2010) turizm sektöründe mesleğin sosyal getirilerinin ve eğlenceli olmasının kariyer bağlılı̆ı sağladığını saptamıştır. Öte yandan emek-yoğun bir sektör olan turizmde, olumsuz çalışma koşullarının çalışan performansını da olumsuz yönde etkilemesi muhtemeldir.

Araştırmada turizm eğitimli otel çalışanlarının mesleki sosyal statü algılarının artmasıyla mesleği bırakma niyetlerinin azaldığı tespit edilmiştir. Dolayısıyla mesleki sosyal statü algısı yüksek olan çalışanların mesleği bırakma niyetleri düşüktür. Bu sonuç ilgili yazında yer alan çalışmaları destekler niteliktedir (Kyriacou vd., 2002; Karakuş 2011; Erdem ve Kayran, 2013; Saltık vd., 2016; Yılmaz ve Tanrıverdi, 2017; Derin vd., 2017). Ayrıca elde edilen bulgular Sosyal Kimlik Teorisi ile örtüşmektedir (Ashforth ve Mael, 1989; Dutton vd., 1994; Riketta, 2005; Liu, Li, Shi ve Fang, 2013). Belli bir gruba dahil olmanın insan psikolojisindeki yerini açıklayan bu teoriden hareketle, mesleki sosyal statünün kariyer kararı üzerinde önemli etkisi olduğu söylenebilir.

Araştırmada yer alan dört değişkene ait genel ortalamalara bakıldığında; çalışanlar, işverenler ve sektör adına çözüme kavuşturulması gereken hususlar olduğu dikkat çekmektedir. Elde edilen istatistiki bulgulara göre otel çalışanlarının iş güvencesizliği algıları orta, olumsuz çalışma koşulları algıları yüksek, mesleki sosyal statü algıları orta ve mesleği bırakma niyetleri orta düzeyde bir ortalamaya sahiptir. Dolayısıyla bu anlamda sektör çalışanlarına, işverenlere ve ülkenin ilgili yönetim birimlerine önemli görevler düşmektedir.

İş güvencesizliği yaşam kalitesini düşürmenin yanında çalışanın örgütsel bağlıığını da olumsuz yönde etkilemektedir. Örgütsel bağlılığı olmayan çalışanın müşteri memnuniyeti sağlaması ise oldukça güçtür. Ayrıca iş güvencesizliği algısı var olan bir sektörde iyi bir mesleki imajdan bahsetmek mümkün değildir. Bu bakımdan özellikle turizm eğitimli çalışanların iş güvencesi algısını artırmak adına turizm meslek yasasının çıkarııması yönünde çaba sarf edilmelidir. Bu noktada ülkenin ilgili yönetim birimlerine önemli görevler düşmektedir. Ayrıca Türkiye' de turizm hacmini geliştirerek daha fazla istihdam ve iş güvencesi sağlamak faydalı olacaktır.

Turizm sektöründe olumsuz çalışma koşullarının iyileştirilmesi adına; zorunlu ve ücretsiz mesai uygulamalarının kaldırıması ve bu konuda gerekli denetlemelerin yapılması önemlidir. Ayrıca nitelikli çalışanların sektörde tutulması sayesinde örgüt-içi kaba vb., olumsuz davranışların önüne geçilebilir. Sektörün mevsimsel özellik göstermesi de olumsuz çalışma koşulları arasındadır. Bu bakımdan alternatif turizm çeşitlerini geliştirilmek ve farklı ülke pazarlarına yönelmek sezonluk istihdam sorununu çözmede faydalı olacaktır.

Turizm sektörünün mesleki sosyal statüsünü olumlu ve olumsuz yönde etkileyen pek çok faktör vardır. Örneğin turizm bölgelerinin genellikle coğrafi imajı iyi yerler olması ve sektör çalışanlarının bu 
bölgelerde ikamet etmesi sektörde çalışmayı değerli kılabilir. Ayrıca sektörün; eğlenceli, insan ilişkilerine yönelik, gelişime açık olması ve turizm sektörünün cari açık kapatmada önemli rol oynaması toplumda olumlu bir algı yaratabilir. Ancak iş güvencesizliği, olumsuz çalışma koşulları, meslek kanunun olmayışı, genellikle beden gücü gerektiren bir iş yapısının var olması toplum nezdinde olumsuz bir algı yaratabilmektedir. Bu bağlamda sektör çalışanlarının çalışma koşullarını iyileştirilmesi ve turizm sektörünün ülke ekonomisindeki rolünün halka yeterince anlatılması önemlidir.

Turizm sektöründe nitelikli hizmet sunmak adına turizm eğitimli çalışanlara ihtiyaç vardır. Ancak Dünyanın çeşitli ülkelerinde ve Türkiye'de yapılan çalışmaların birçoğu özellikle turizm eğitimi alan mezunların bir süre sonra mesleği bıraktıklarını ortaya koymuştur (Kuşluvan ve Kuşluvan, 2000; King, McKercher ve Wayszak, 2003; Aksu ve Köksal, 2005; Duman, Tepeci ve Unur, 2006; Blomme, Tromp ve Rheede, 2008). Bu durumun önüne geçmek adına öncelikle mezunlarda istihdam algısının oluşması sağlanmalı; iş güvencesizliği, çalışma koşullarının iyileştirilmesi ve turizm mesleği imajının iyileştirilmesi adına çalışmalar yapılmadır. Bu noktada başta ülkenin ilgili yönetim birimlerine ve işverenlere önemli görevler düşmektedir.

Araştırmada elde edilen veriler; sektör çalışanlarını, konaklama işletmelerini ve turizm sektörünü olumsuz yönde etkileyebilecek bir takım soruna işaret etmektedir. Bu bakımdan ilerleyen zamanlarda iş güvencesizliği, olumsuz çalışma koşulları, mesleki sosyal statü ve mesleği bırakma niyeti arasındaki ilişkinin farklı turistik evren ve örneklemler üzerinde ölçümlenmesi faydalı olabilir. Ayrıca turizm sektörü çalışanlarına yönelik çalışmalarda turizm eğitimli çalışanların durumlarıyla ilgili araştırmalara yer vermek tespitte bulunmak ve çözüm önerileri getirmek bakımından önemlidir. Bununla birlikte araştırma modelinin farklı sektör çalışanları üzerinde test edilmesi de mesleki bağlılık düzeyi yordayıcılarının belirlenmesi bakımından önemli olabilir. Araştırma modelinde yer alan bağımsız değişkenler arasında korelasyon olduğu da tespit edilmiştir. Dolayısıyla bundan sonra yapılacak çalışmalarda söz konusu değişkenler arasındaki ilişki ve etkinin ölçümlenmesi faydalı olacaktır.

Bu araştırma yapılırken temel hedef turizm eğitimli otel çalışanlarının iş güvencesizliği, çalışma koşulları ve mesleki sosyal statü algılarının mesleki bırakma niyetleri üzerindeki etkisini belirlemektir. Çalışmanın verileri 2019 yılı Temmuz- Eylül ayları arasında ve Antalya'da faaliyet gösteren belirli otel işletmelerinden elde edilmiştir. Dolayısıyla bulgular söz konusu zaman ve işletme çalışanları ile sınırlı olup kapsamlı genellemeler yapmaya imkan vermemektedir. Aynı zamanda anket uygulaması söz konusu otel işletmelerinin izni ile yapıldığından ve otel çalışanlarının bu durumu bilmeleri nedeniyle hawthorne etkisine maruz kalmış olabilecekleri de ihmal dahilindedir. Ancak bu durumu önlemek amacıyla anket uygulaması yapılırken çalışanlardan isim bilgisi alınmamış ve bu durum kendilerine hatırlatılmıştır. Dolayısıyla bu çalışmada elde edilen bulguların, katılımcıların öznel değerlendirmelerine yönelik olduğu için sonuçların nesnelliği ve genellenebilirliği de bu kısıtlar çerçevesinde değerlendirilebilir. Bu bakımdan mevcut konuda kapsayıcı genellemelere varabilmek ve daha güçlü sonuçlara ulaşabilmek için değişkenler farklı metodolojik yaklaşımlarla ele alınabilir ve böylece ilgili literatürün zenginlik kazanmasına da katkıda bulunulabilir.

\section{Beyan ve Açıklamalar (Disclosure Statements)}

1. Bu çalışmanın yazarları, araştırma ve yayın etiği ilkelerine uyduklarını kabul etmektedirler (The authors of this article confirm that their work complies with the principles of research and publication ethics).

2. Yazarlar tarafından herhangi bir çıkar çatışması beyan edilmemiştir (No potential conflict of interest was reported by the authors).

3. Bu çalışma, intihal tarama programı kullanılarak intihal taramasından geçirilmiştir (This article was screened for potential plagiarism using a plagiarism screening program). 


\section{Kaynaklar}

Adler, N. E., \& Stewart, J. The MacArthur scale of subjective social status. http://www.macses. ucsf.edu/research/psychosocial/subjective.php (Erişim Tarihi: 06. 01. 2020).

Akbıyık, B. S. U. (2016). The association between perceived job insecurity and career commitment in hospitality sector: The role of support at work. Research Journal of Business and Management, 3(1), 11-21.

Akkaşoğlu, S., \& Ulama, ş. (2016). İ̧̧örenlerin çalışma koşulları ve iş tatmini: istanbul'da beş yıldızlı konaklama işletmelerinde bir araştırma. International Congress of Tourism \& Management Researches, Antalya. https://www.researchgate.net/publication/312380072_ (Erişim Tarihi: 07.12.2019).

Aksu, A., \& Köksal, C. D. (2005). Perceptions and attitudes of tourism students in Turkey. International Journal of Contemporary Hospitality Management, 17(5), 436-447.

Ashforth, B. E., \& Mael, F. (1989). Social identity theory and the organization. Academy of Management Review, 14(1), 20-39.

Baltes, P. B., \& Baltes, M. M. (1990). Psychological perspectives on successful aging: The model of selective optimization with compensation. In P. B. Baltes (Ed.), Successful aging: Perspectives from the behavioral sciences (pp. 1-34). New York, NY: Cambridge University Press.

Bamford, K. (2012). Undergraduate student perceptions of a career in the tourism and hospitality industry in New Zealand. University of Otago, Master Thesis of Tourism.

Blomme, R. J. (2006). Eindrapportage associate degree the hague. The Netherlands: Hotelschool.

Blomme, B., Tromp, D., \& Rheede, A. V. (2008). Predictors of turnover intentions of highly-educated employees in the hospitality industry. Advances in Hospitality and Leisure, 4(1), 3-28.

Bozkurt, H. Ö., \& Demirel, Z. H. (2019) Otel işletmelerinde işten ayrılma niyetinin yordayıcısı olarak iş güvencesi algısı: İşe gömülmüşlüğün aracı rolü. Business \& Management Studies: An International Journal, 7(4), 1383-1404.

Bozkurt, H. Ö., \& Özkoç, A. G. (2019). Çalışanlarda öznel iyi olma halinin algılanan istihdam edilebilirlik ve işten ayrılma niyeti ile ilişkisi: Konaklama işletmelerinde bir uygulama. Journal of Tourism and Gastronomy Studies, 7(1), 265285.

Chen, J. S., Chu, K. H., \& Wu, W. C. (2000). Tourism students' perceptions of work values: A case of Taiwanese universities. International Journal of Contemporary Hospitality Management, 12(6), 360-365.

Cooper, C. L., \& Cartwright, S. (1994). Healty mind; healty organization a proactive approach to occupational stress. Human Relations, 47(4), 455-471.

Çiftçioğlu, A. (2011). Investigating occupational commitment and turnover intention relationship with burnout syndrome. Business and Economics Research Journal, 2(3), 109-119.

Çokluk, Ö., Şekercioğlu, G., \& Büyüköztürk, Ş. (2010). Sosyal bilimler için çok değişkenli istatistik: SPSS ve LISREL uygulamaları. Ankara: Pegem.Net.

Derin, N., Ilkım, N. Ş., \& Yayan, H. (2017). Hemşirelerde mesleki bağlılığın mesleki prestijle açıklanması. Hacettepe Üniversitesi Hemşirelik Fakültesi Dergisi, 4(3), 24-37

De Witte, H. (1999). Job insecurity and psychological well-being: Review of the literature and exploration of some unresolved issues. European Journal of Work and Organizational Psychology, 8(2), 155-177.

Duman, T., Tepeci, M., \& Unur, K. (2006). Mersin'de yükseköğretim ve orta öğretim düzeyinde turizm eğitimi almakta olan öğrencilerin sektörün çalışma koşullarını algılamaları ve sektörde çalışma isteklerinin karşılaştırmalı analizi. Anatolia: Turizm Araştırmaları Dergisi, 17(1), 51-69.

Dutton, J. E., Dukerich, J. M., \& Harquail, C. V. (1994). Organizational images and member identification. Administrative Science Quarterly, 39, 239-263.

Eke, B. (1987). Bir sosyal sınıf belirleyicisi olarak meslek faktörü. istanbul Üniversitesi iktisat Fakültesi Mecmuası, 14(1), 377-401.

Emir, O., Pelit, E., \& Arslan, S. (2010). Turizm alanında önlisans eğitimi alan öğrencilerin staj öncesi ve sonrası görüşlerinin karşılaştırılması (Afyon Kocatepe Üniversitesi örneği). Elektronik Sosyal Bilimler Dergisi, 9(33), 141-165.

Erdem, B., \& Kayran, M. F. (2013). Balıkesir Üniversitesi turizm işletmeciliği ve otelcilik yüksekokulu öğrencilerinin meslek seçimini etkileyen faktörler üzerine bir araştırma. C.Ü. IiBF Dergisi, 14(1), 81-106.

Erdil, O., Keskin, H., İmamoğlu, S. Z., \& Erat, S. (2004). Yönetim tarzı ve çalışma koşulları, arkadaşıı ortamı ve takdir edilme duygusu ile iş tatmini arasındaki ilişkiler: Tekstil sektöründe bir uygulama. Doğuş Üniversitesi Dergisi, 5(1), $17-26$. 
Ferreira, W. A., Camelo, L., Viana, M. C., Giatti, L., \& Barreto, S. M (2018). Is subjective social status a summary of lifecourse socioeconomic position? Reports In Public Health, 34(5), 1-12.

Flinkman, M., Isopahkala-Bouret, U., \& Salantera, S. (2013). Young registered nurses' intention to leave the profession and professional turnover in early career: A qualitative case study. International Journal of Nursing Studies, 1(1), 727-739.

Greenhalgh, L., \& Rosenblatt, Z. (1984). Job insecurity: Toward conceptual clarity. Academy of Management Review, 9(1), 438-448.

Habip, E., \& Sazkaya, M. K. (2019). Mesleki prestijin işten ayrılma niyeti üzerindeki etkisinde kolektif şükranın aracılık rolü: Ulaşım sektöründe bir araştırma. Uluslararası Yönetim Iktisat ve Işletme Dergisi, 15(3), 834-857.

Hartley, J., Jacobsson, D., Klandermans, B., \& Van Vuuren, T. (1991). Job insecurity. London: Sage Publications.

Heckausen, J. (1997). Developmental regulation across adulthood: Primary and secondary control of age-related challenges. Developmental Psychology, 33, 176-187.

Hellgren, J., Sverke, M., \& Isaksson, K. (1999). A two-dimensional approach to job insecurity: Consequences for employees' attitudes and well-being. European Journal of Work and Organisational Psychology, 8(2), 179-195.

Herzberg, F, Mausner, B., \& Snyderman, B. B. (1959). The motivation to work. New York: Wiley.

Herzberg, F. (1966). Work and the nature of man. Cleveland, $\mathrm{OH}$ : World Publishing.

Hobfoll, S. (1989). Conservation of resources: A new attempt at conceptualizing stress. The American Psychologist, 44, 513-524.

İzgi, B. B., \& Olcay, A. (2008). Çalışma koşullarının önemi: Gaziantep ilindeki 4 ve 5 yıldızlı otel işletmesi çalışanlarına yönelik bir araştırma. Gazi Üniversitesi Iktisadi ve Idari Bilimler Fakültesi Dergisi, 10(1), 43-62.

Jacqueline, M., \& Milton, M. (2007). The creative environment's influence on intent to turnover: A structural equation model and analysis. Management Research News, 31(1), 41-56.

Joelson, L., \& Wahlouist, L. (1987). The psychological meaning of job insecurity and-job loss: Resuits of a longitudina study. Sot. Sci. Med., 25(1), 179-182.

Karacaoğlu, K. (2015). Çalışanların iş güvencesizliğinin işten ayrılma niyetleri üzerindeki etkisi: Alanya bölgesindeki beş yıldızlı otellerde bir araştırma. Uluslararası Alanya Iş̧letme Fakültesi Dergisi, 7(1), 13-21.

Karakuş, H. (2011). Hemşirelerin iş tatmin düzeyleri: Sivas ili örneği. Dicle Üniversitesi Sosyal Bilimler Enstitüsü Dergisi, 3(6), 46-57.

King, B., Mckercher, B., \& Waryszak, R. (2003). A comparative study of hospitality and tourism graduates in Australia and Hong Kong. International Journal of Tourism Research, 5(1), 409-420.

Kozak, M. A., \& Kızılırmak, İ. (2001). Türkiye'de meslek yüksekokulu turizm otelcilik programı öğrencilerinin turizm sektörüne yönelik tutumlarının demografik değişkenlere göre değişimi: Anadolu, Akdeniz ve Karedeniz Teknik Üniversitesi öğrencileri üzerine bir uygulama. Anatolia: Turizm Araştırmaları Dergisi, 12(Bahar), 9-16.

Krieger, N., Williams, D. R., \& Moss, N. E. (1997). Measuring social class in U.S. public health research: Concepts, methodologies, and guidelines. Annual Review of Public Health, 18(1), 341-378.

Kuşluvan, S., \& Kuşluvan, Z. (2000). Perceptions and attitudes of undergraduate tourism students towards working in the tourism industry in Turkey. Tourism Management, 21(3), 251-269.

Kuşluvan, S., Kuşluvan, Z., \& Eren, D. (2003). Undergraduate tourism students' satisfaction with student work experience and its impact on their future career intentionss: A case study. S. Kuşluvan (Ed.), Managing employee attitudes and behaviors in the tourism and hospitality industry içinde (77-98). New York: Nova Science Publishers Inc.

Kültür ve Turizm Bakanlığı (2019). https://yigm.ktb.gov.tr/TR-201136/turizm-yatirim-ve-isletme-bakanlik-belgeli-tesisistati-.html (Erişim Tarihi: 18.11.2019).

Kültür ve Turizm Bakanlığı (1989). Otelcilik ve turizm endüstrisinde işgücü araştırması. Ankara: T.C. Turizm Bakanlığı.

Kyriacou, C., Coulthard, M., Hultgren, A., \& Stephens, P. (2002). Norwegian University students' views on a career in teaching. Journal of Vocational Education and Training, 54(1), 103-16.

Laine, M., Van der Heijden, B. I. J. M., Wickstrom, G., Hasselhorn, H. M., \& Tackenberg, P. (2009). Job insecurity and intent to leave the nursing profession in Europe. International Journal of Human Resource Management, 20(2), 420-438.

Lee, C. H., \& Bruvold, N. T (2003). Creating value for employees: Investment in employee development. Int. J. Human Res. Manag., 14(6), 981-1000. 
Liu, Z., Cai, Z., Li, J., Shi, S., \& Fang, Y. (2013). Leadership style and employee 137 turnover intentions: A social identity perspective. Career Development International, 18, 305-324.

Lu, T., \& Adler, H. (2009). Career goals and expectations of hospitality and tourism students in China. Journal of Teaching in Travel \& Tourism, 9, 63-80.

Mauno, S., De Cuyper, N., Tolvanen, A., Kinnunen, U., \& Mäkikangas, A. (2014). Occupational well-being as a mediator between job insecurity and turnover intention: Findings at the individual and work department levels. European Journal of Work and Organizational Psychology, 23(3), 381-393.

Meier, K. J., \& Hicklin, A. (2008). Employee turnover and organizational performance: Testing a hypothesis from classical public administration. Jpart, 18(1), 573-590.

Meydan, C. H., \& Şeşen, H. (2011). Yapısal eşitlik modellemesi Amos uygulamaları. Ankara: Detay Yayıncılık.

Mitchell, J. C., \& Epstein, A. L. (1959). Occupational prestige and social status among urban Africans in Northern Rhodesia. Africa: Journal of the International African Institute, 29(1), 22-40.

Munro, B. H. (2005). Statistical methods for health care research. Massachusetts: Lippincott Williams \& Wilkins.

Önder, Ç., \& Wasti, A. S. (2002) İş güvencesi endeksi ve iş güvencesi memnuniyeti ölçeği: Güvenilirlik ve geçerlilik analizi. Yönetim Araştırmaları Dergisi, 2(1), 23-47.

Pavesic, D. V., \& Brymer, R. A. (1990). Job satisfaction: What'shappeningto the young managers. Cornell Hotel and Restaurant Administration Quarterly, 31(1), 90-96.

Probst, T. M. (1998). Antecedents and concequences of job insecurity: An integrated model. University of Illionis, PhD Thesis, Urbana.

Riketta, M. (2005), Organizational identification: A meta-analysis. Journal of Vocational Behavior, 66(2), 358-384.

Roney, S. A., \& Öztin, P. (2007). Career perceptions of undergraduate tourism students: A case study in Turkey. Journal of Hospitality, Leisure, Sport and Tourism Education, 6(1), 4-17.

Saltık, I. A., Avcı, U., \& Kaya, U. (2016). Mesleki bağıılık ve mesleği bırakma niyeti üzerinde etken faktörler olarak bireymeslek uyumu ve mesleğin sosyal statüsü: Turizm sektöründe görgül bir çalışma. İşletme Araştırmaları Dergisi, 8(3), 42-63.

Seymen, O., Bolat, T., Bolat, O. I., \& Kinter, O. (2017). Turizm sektöründe çalışma koşulları algısı, hizmet verme yatkınlığı ve mesleki yabancılaşma ilişkisi: turizm eğitimi alan öğrenciler açısından bir değerlendirme. MANAS Sosyal Araştırmalar Dergisi, 6(3), 401-430.

Sverke, M., Hellgren, J., \& Naswall, K. (2002). No security: A meta-analysis and review of job insecurity and its consequences. J Occup Health Psychol., 7(1), 242-264.

Şahin, B., \& Karataş, A. (2015). Çalışma koşulları, iş tatmini ve sektörel bağlılık ilişkisi: Otel çalışanları üzerinde bir araştırma. I. Avrasya uluslararası turizm kongresi güncel konular, eğilimler ve göstergeler (ss. 607-619). Konya: Aybil Yayınları.

Tajfel, H. (1981). Human groups and social categories. Cambridge: Cambridge University Press.

Tajfel, H., \& Turner, J. (1985). The social identity theory of intergroup behavior. In S. Worchel and W. Austin (Eds.), Psychology of intergroup relations (pp. 7-24). Chicago: Nelson-Hall.

Tunç, P., Gitmez, A., \& Boothby, M. R. (2014). Yoğun bakım ve yataklı servis hemşirelerinde duygusal emek stratejilerinin empatik eğilim açısından incelenmesi. Anadolu Psikiyatri Dergisi, 15(1), 45-54.

Turner, J. C. (1975). Social comparisons and social identity: Some prospects for intergroup behavior. European Journal of Social Psychology, 5, 5-34.

Turunç, Ö. (2011). Örgütsel adaletin çalışanların özdeşleşme ve işten ayrılma niyetine etkisi: Örgütsel özdeşleşmenin aracılık rolü. “Işs, Güç” Endüstri îlişkileri ve insan Kaynakları Dergisi, 13(1), 145-168.

Tutkun, Ö. F., \& Koç, M. (2008). Atfedilen kalıp yargılar. Ankara Üniversitesi Eğitim Bilimleri Fakültesi Dergisi, 41(1), 255273.

Üzümcü, T. P. Alyakut, O., \& Günsel, A. (2015). Turizm eğitimi alan öğrencilerin mesleğin geleceğine ilişkin bakış açıları. Balıkesir Üniversitesi Sosyal Bilimler Enstitüsü Dergisi, 18(33), 179-199.

Vance, R. J., \& Kuhnert, K. W. (1989). Job and employment security and security valence: Interactive effects on employment adjustment. Paper presented at the Annual Convention of the American Psychological Association.

Van Dick, R., Christ, O., Stellmacher, J., Wagner, U., Ahlswede, O., Grubba, C., Hauptmeier, M., Hohfeld, C., Moltzen, K., \& Tissington, A. (2004). Should i stay or should i go? Explaining turnover intentions with organizational identification and job satisfaction. Bri. J. Manag., 15(1), 351-60. 
Walsh, K., \& Taylor, M. S. (2007). Developing in-house careers and retaining management talent: What hospitality professionals want from their jobs. Cornell University School of Hotel Administration, 48(2), 163-182.

Waltz, C. F., Strcikland, O. L., \& Lenz, E. R. (2010). Measurement in nursing and health research. New York: Springer Publishing Company.

Weng, Q., \& James, C. M. (2012). Organizational career growth, affective occupational commitment and turnover intentions. Journal of Vocational Behavior, 80(2), 256-265.

Yıldırım, B. I., \& Yirik, Ş. (2014). İş görenlerin iş güvencesi algıları ve işten ayrılma niyetleri ilişkisi: Belek bölgesi beş yıldızlı otel çalışanları örneği. Iğdır Üniversitesi Sosyal Bilimler Dergisi, 6(1), 123-140.

Yılmaz, A., \& Tanrıverdi, H. (2017). Aşçıların meslek uyumu ve meslek algısı düzeyleri üzerine bir araştırma. Karabük Üniversitesi Sosyal Bilimler Enstitüsü Dergisi, 7(2), 621-639. 
This Page Intentionally Left Blank 